\title{
Synthesis of Novel 2,3-Disubstituted Quinazolin-4-(3H)-ones and Their Antibacterial Activity on the Ultra-structure of Some Pathogenic Microorganisms
}

\author{
M. R. Mahmoud ${ }^{1}$, Salwa S. Abdelwahab ${ }^{2 *}$ and K. F. Saied ${ }^{3}$ \\ ${ }^{1}$ Chemistry Department, Faculty of Science, Ain Shams University, 11566, e-mail: mahmoud_ \\ akl@sci.asu.edu.eg ${ }^{2}$ Faculty of Pharmaceutical Sciences \&Pharmaceutical Industries, \\ Future University in Egypt 11835 and ${ }^{3}$ Chemistry Department, Faculty of Pharmaceutical \\ Science, Nahda University, Mrorst., 62517, East Beni-Suef, Beni-Suef, Egypt, e-mail: \\ fathykhaled905_7@yahoo.com
}

\begin{abstract}
SERIES of highly functionalized quinazolin-4-ones, with different substituents at position 3, have been concisely synthesized in good yields, via the reactions of 3-amino-6-bromo-2-undecyl-quinazoline-4(3H)-one with one carbon donor phenyl isothiocyante, followed by $\alpha$-chlorinated compounds and 1,2-dichloroethanone. Moreover, reactions of 6-bromo-2-undecyl-4H-benzo-[3,1] oxazin-4-one with different hydrazides were also examined, giving new 3-substituted quinazolin-4-one derivatives. Some of the new quinazolin-4-ones were screened against gram negative and positive bacteria and showed good to moderate antibacterial activity. Structures of all new synthesized compounds in this investigation were substantiated using spectroscopic IR, ${ }^{1} \mathrm{H}-\mathrm{NMR}$ and MS studies.
\end{abstract}

Keywords: Antibacterial; 1,3-benzoxazin-4-one; quinazolino-4-ones; hydrazides; 1,3-thiazolidin4-ones.

The fused heterocyclic quinazolin-4-one and related derivatives are of considerable interest due to their wide range of biological properties, for example, anti-tumor[1], antimicrobial[2], antifungal[3] and antibacterial [4]. Moreover, the quinazolin-4-one ring is a frequently encountered unit in natural products, such as L-Vasicinone[5] and chrysogine[6] and in drugs, such as methaqualone[7], isofebrifugine[8] and febrifugine[9]. Aforementioned findings prompted the authors to synthesize a variety of new 2,3-disubstituted quinazolin-4-one derivatives, using the key starting 6-bromo-2-undecylbenzo $[3,1]$ oxazin-4-one[10]. Furthermore, some of the prepared quinazolin-4-one derivatives were used as precursors for synthesis of 1,3-thiazolidin-4ones and its derivatives which is an important ring for its wide biological applications[11-13]. Thus, by merging of these two biologically active hetero-rings together, it was hoped to obtain some new compounds of anticipated pharmaceutical interest.

\section{Experimental}

General

IR spectra were recorded on a Pye-Unicam SP 1200 spectrophotometer using the KBr Wafer technique for solid materials. The 1H-NMR spectra were determined on MHz 300 using TMS, in (DMSO-d6) otherwise stated. The patterns of the undecyl group protons $(23 \mathrm{H})$ appeared in the spectra of all measured compounds at $\delta$ ppm: $\approx 2.37(\mathrm{t}, 2 \mathrm{H}), 1.72(\mathrm{~m}, 2 \mathrm{H}), 1.42(\mathrm{~m}, 16$ $\mathrm{H}), 0.91\left(\mathrm{t}, 3 \mathrm{H}, \mathrm{CH}_{3}\right), \mathrm{J}$ constants for 2- and 3 -adjacent aromatic protons $\approx 6-8$ and $2-3 \mathrm{H}_{\mathrm{Z}}$, respectively. Mass spectra were determined using an HP model MS-5988 in EI mode with electron energy $70 \mathrm{ev.} \mathrm{Elemental} \mathrm{analysis} \mathrm{was} \mathrm{carried} \mathrm{out}$ at the Micro Analytical Unit, Faculty of Science, Cairo University using a Perkin-Elemer 2400 CHN Elemental Analyzer. Light petroleum was referred to the fraction b.p. $=60-80^{\circ} \mathrm{C}$. TLC was performed on Merck Kieselgel 60 F254 aluminum packed plates. 2-Cyanoacetohydrazide[14] and 
2-benzylidenemalononitrile[15] were prepared early.

\section{Synthesis of oxazin-4-one 1}

A mixture of 2-amino-5-bromobenzoic acid $(2.15 \mathrm{~g}, 0.01 \mathrm{~mol})$ and dodecanoyl chloride $(2.2 \mathrm{~g}$, $0.01 \mathrm{~mol})$ was refluxed in pyridine $(20 \mathrm{ml})$ for three hours. After cooling, the reaction mixture was diluted with cold water and then acidified with dilute hydrochloric acid. The solid deposited was filtered off and recrystallized from benzene. one (1)

6-Bromo-2-undecyl-(4H)-benzo[d][1,3]oxazin-4-

Yield 2.15 g 56\%, pale yellow crystals, mp 92-94º C. IR (KBr) 2956, 2880, 1757, $1642 \mathrm{~cm}^{-1}$. 1H-NMR (300 MHz, CDCl3) $\delta: 7.32$ (d, 1H, Ar-H), 7.81 (d, 1H, Ar-H), 8.63 (s, 1H, Ar-H). Ms m/z: 380 (M, 100), 300 (12.6), 238 (63.8), 181(22.). Anal. Calcd for C19H26BrNO2: C, 60.0; H, 6.84; N, 3.68. Found: C, 60.31; H, 6.63; N, 3.66 .

\section{Synthesis of quinazolinone derivatives}

Synthesis of quinazolinones 2-5

A mixture of benzoxazinone $1(1.14 \mathrm{~g}, 0.03 \mathrm{~mol})$ and hydrazine hydrate $(0.15 \mathrm{~g}, 0.03 \mathrm{~mol})$, ethyl carbazate $(0.31 \mathrm{~g}, 0.03 \mathrm{~mol})$, 4-tolylsulfonohydrazide $(0.56 \mathrm{~g}, 0.03 \mathrm{~mol})$ and $/$ or 2-cyanoacetohydrazide $(0.30 \mathrm{~g}, 0.03 \mathrm{~mol})$ in dioxane $(20 \mathrm{ml})$ was stirred for two hours at room temperature. After cooling, the solid separated was filtered off, dried and recrystallized from the proper solvent.

3-Amino-6-bromo-2-undecylquinazolin-4one (2): Yield $0.80 \mathrm{~g} 68 \%$, yellow crystals, mp 202-204 ${ }^{\circ} \mathrm{C}$ (ethanol). IR (KBr) 3403, 3319, 3167, 2960, 2886, $1688 \mathrm{~cm}-1$. 1H-NMR (300 MHz, DMSO-d6) $\delta: 6.11$ (br.s, 2H, NH2), 7.34 (d, 1H, Ar-H), 7.78 (d, 1H, Ar-H), 8.66 (s, 1H, Ar-H). MS m/z: 393 (M, 73.2), 313 (12.7). Anal. Calcd for C19H28BrN3O: C 57.86; H, 7.10; N, 10.65 . Found: C, 58.08; H, 7.0; N, 10.68.

Ethyl(6-bromo-4-oxo-2-undecylquinazolin-3(4H)-yl) carbamate (3): Yield $0.60 \mathrm{~g} 44 \%$, yellow crystals, mp $196-198^{\circ} \mathrm{C}$ (ethanol). IR (KBr) 3289 , 2966, 2838, 1702, 1677, $1617 \mathrm{~cm}-1$. 1H-NMR (300 MHz, CDCl3) $\delta: 1.71(\mathrm{t}, 3 \mathrm{H}, \mathrm{J}=5.6, \mathrm{CH} 3)$, 3.88 (q, 2H, J = 5.6, CH2), 7.33 (d, 1H, Ar-H), 7.80 (d, 1H, Ar-H), 8.58 (s, 1H, Ar-H), 9.3 (s, 1H, NH). MS m/z: 465 (M, 14.7), 327 (100), 315 (40.4). Anal. Calcd for $\mathrm{C} 22 \mathrm{H} 32 \mathrm{BrN} 3 \mathrm{O} 3$ : C, 56.65; H, 6.86; N, 9.0. Found: C, 56.34; H, 6.77; Egypt.J.Chem. 60 , No.6 (2017)

\section{$\mathrm{N}, 8.82$.}

N-(6-bromo-4-oxo-2-undecylquinazolin3(4H)-yl)-4-methylbenzenesulfonamide (4):Yield $0.70 \mathrm{~g} 43 \%$, yellow crystals, $\mathrm{mp}>300^{\circ} \mathrm{C}$ (dioxane). IR (KBr) 3211, 2973, 1692 cm-1. 1H-NMR (300

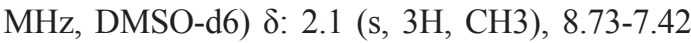
(m, 7H, Ar-H), 8.9 (s, 1H, NH). MS m/z: 549 ([M.+]+2, 27.3), 547 ([M.+], 36.9), 408 (70.2), 329 (37.8), 91 (100), 65 (33.2 ). Anal. Calcd for C26H34BrN3O3S: C, 56.93; H, 6.2; N, 7.66. Found: C, 56.86; H, 6.09; N, 7.34.

N-(6-bromo-4-oxo-2-undecylquinazolin-3-

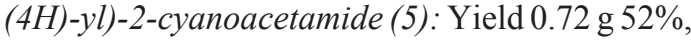
pale yellow crystals, mp $280-282^{\circ} \mathrm{C}$ (methanol). IR (KBr) 3203, 2262, 1692, $1680 \mathrm{~cm}-1$. 1H-NMR (300 MHz, DMSO-d6) $\delta: 4.40(\mathrm{~s}, 2 \mathrm{H}, \mathrm{CH} 2)$, 7.37 (d, 1H, Ar-H), 7.75 (d, 1H, Ar-H), 8.62 (s, 1H, Ar-H), 10.2 (s, 1H, NH). MS m/z: $463(\mathrm{M}+2$, 18.0), 460 (M, 42.1 ), 379 (31.9), 160 (100). Anal. Calcd for C22H29BrN4O2: C, 57.26; H, 6.29; N, 12.14. Found: C, 57.6; H, 6.31; N, 12.01.

\section{Synthesis of pyrazolo[1,5-c]quinazolinone 6}

A suspension of acetamide $5(1.0 \mathrm{~g})$ in dioxane $(20 \mathrm{ml})$ was heated for two hours with piperidine $(0.5 \mathrm{ml})$. The reaction mixture was cooled, concentrated $(5 \mathrm{ml})$ and acidified with dilute hydrochloric acid. The solid separated was filtered off, washed several times with dilute methanol and crystallized from dioxane.

9- Bromo-2-oxo-5-undecyl-2,3dihydropyrazolo[1,5-c]quinazoline-1-carbonitrile (6)

Yield $0.73 \mathrm{~g} 76 \%$, yellow crystals, mp 305 $307^{\circ} \mathrm{C}$. IR (KBr) 3283, 2120, $1676 \mathrm{~cm}-1$. 1H-NMR

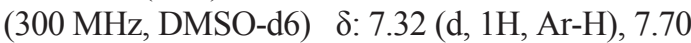
(d, 1H, Ar-H), 8.53 (s, 1H, Ar-H), 10.0 (s, 1H, NH). MS m/z: 400 (M- NCO, 100), 303 (15.2). Anal. Calcd for. C22H27BrN4O: C, 59.59; H, 6.09; N, 12.64. Found: C, 60.09; H, 6.0; N, 12.36 .

\section{Synthesis of quinazolinones (E,Z)-7a-c}

Following the literatures[16-19], a suspension of finally powdered potassium hydroxide $(0.17 \mathrm{~g}$, $0.03 \mathrm{~mol})$ in dry dimethyl formamide $(15 \mathrm{ml})$, phenyl isothiocyanate $(0.40 \mathrm{~g}, 0.03 \mathrm{~mol})$ and amine $2(1.18 \mathrm{~g}, 0.03 \mathrm{~mol})$ were added. The reaction mixture was stirred at room temperature for an hour, then, 2-chloroacetonitrile $(0.23 \mathrm{~g}, 0.03 \mathrm{~mol})$, 1-chloropropan-2-one $(0.28 \mathrm{~g}, 0.03 \mathrm{~mol})$ and/or ethyl 2-chloro-3-oxobutanoate $(0.50 \mathrm{~g}, 0.03 \mathrm{~mol})$ was added. The whole mixture was heated under 
reflux for three hours and left overnight. The reaction mixture was poured onto ice cold water and acidified with $0.1 \mathrm{~N}$ hydrochloric acid at $\mathrm{PH}$ 3-4. The resulting precipitate was filtered off, dried and recrystallized from the proper solvent.

(E,Z)-3-((4-Amino-3-phenylthiazol-2(3H)ylidene) amino)-6-bromo-2-undecylquinazolin-

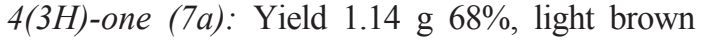
crystals, mp $211-213^{\circ} \mathrm{C}$ (methanol). IR (KBr) 3490, 3265, 3108, 1676, $1614 \mathrm{~cm}-1$. 1H-NMR (300 MHz, DMSO-d6) $\delta: 4.38(\mathrm{~s}, 1 \mathrm{H},=\mathrm{CH}), 7.36-8.40(\mathrm{~m}$, 8H, Ar-H), 10.22 (br.s, 2H, NH2). MS m/z: 569 $([\mathrm{M} .+]+2,27.1), 568(\mathrm{M}+1,0.7), 567(\mathrm{M}, 100)$. Anal. Calcd for C28H34BrN5OS: C, 59.15; H, 5.98; N, 12.32; S, 5.63. Found: C, 59.42; H, 6.08; N, 12.33; S, 5.41.

(E,Z)-6-Bromo-3-((4-methyl-3-phenylthiazol2(3H)-ylidene) amino)-2-undecylquinazolin-

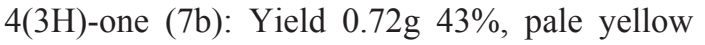
crystals, mp $256-258^{\circ} \mathrm{C}$ (dioxane). IR (KBr) 1674 , $1627 \mathrm{~cm}-1$. 1H-NMR (300 MHz, DMSO-d6) $\delta$ : $2.42(\mathrm{~s}, 3 \mathrm{H}, \mathrm{CH} 3), 4.46(\mathrm{~s}, 1 \mathrm{H},=\mathrm{CH}), 8.10-7.22(\mathrm{~m}$, 8H, Ar-H). MS m/z: 487 (M- Br, 100), 347 (17.2), 77 (83.9). Anal. Caled for C29H35BrN4OS: C, 61.37; H, 6.17; N, 9.87; S, 5.64. Found: C, 61.02; $\mathrm{H}, 6.07 ; \mathrm{N}, 9.9 ; \mathrm{S}, 5.73$.

Ethyl(E,Z)-2-((6-bromo-4-oxo-2undecylquinazolin-3(4H)-yl)imino)-4-methyl-3-phenyl2,3-dihydrothiazole-5-carboxylate (7c):Yield $1.13 \mathrm{~g}$ $60 \%$, yellow crystals, mp $237-239^{\circ} \mathrm{C}$ (methanol). IR (KBr) 2948, 2915, 1728, 1677, $1605 \mathrm{~cm}-1.1 \mathrm{H}$ NMR (300 MHz, DMSO-d6) $\delta: 1.18(\mathrm{t}, \mathrm{J}=7.2$, $3 \mathrm{H}, \mathrm{CH} 3$ ), 2.18 (s, 3H, CH3), 4.20 (q, J = 7.2, $2 \mathrm{H}, \mathrm{CH} 2), 8.64-7.42$ (m, 8H, Ar-H). Anal. Calcd for C32H39BrN4O3S: C, 60.09; H, 6.10; N, 8.76. Found: C, 60.47; H, 6.22; N, 8.8.

\section{Synthesis of quinazolinone 8}

To a stirred solution of compound $2(1.18 \mathrm{~g}$, $0.03 \mathrm{~mol})$ in dimethyl formamide $(15 \mathrm{ml})$, 1,2-dichloroethanone $\quad(0.34 \mathrm{~g}, \quad 0.03 \mathrm{~mol}) \quad$ was added and the mixture was stirred for 30 minutes to form the intermediate IV. Then, the whole mixture was heated with stirring for six hours with potassium thiocyanate $(0.30 \mathrm{~g}, 0.03 \mathrm{~mol})$. The reaction mixture was cooled, poured onto icecold water and acidified with dilute hydrochloric acid. The resulting solid was filtered off, dried and recrystallized from dioxane.
3-(6-Bromo-4-oxo-2-undecylquinazolin-3(4H)-

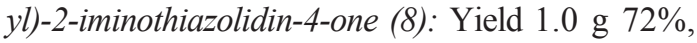
yellowish-white crystals, mp $266-268^{\circ} \mathrm{C}$. IR (KBr) 3382, 1732, 1677, $1618 \mathrm{~cm}-1.1 \mathrm{H}-\mathrm{NMR}$ (300 MHz, DMSO-d6) $\delta: 4.15$ (s, 2H, CH2), $7.54(\mathrm{~d}, 1 \mathrm{H}, \mathrm{Ar}-\mathrm{H}), 8.42(\mathrm{~s}, 1 \mathrm{H}, \mathrm{Ar}-\mathrm{H}), 8.23$ (d, $1 \mathrm{H}$, Ar-H), $9.83(1 \mathrm{H}$, br.s, NH). MS m/z: $494(\mathrm{M}+2,17), 492$ (M, 80.9), 300 (56.6), 273 (40.2), 116 (100), 77 (70.7). Anal. Calcd for C22H29BrN4O2S: C, 53.54; H, 5.88; N, 11.35; S, 6.49. Found: C, 53.77; H, 6.0; N, 11.08; S, 6.22 .

Synthesis of the (dimethylamino)methylene (E,Z)-9

A mixture of the thiazolidinone $8(1.0 \mathrm{~g}$, $0.02 \mathrm{~mol}$ ) and dimethylformamide-dimethylacetal $(0.24 \mathrm{~g}, 0.02 \mathrm{~mol})$ dissolved in $20 \mathrm{ml}$ of toluene, and refluxed for 6 hours. The solid separated on hot was collected by filtration, dried and recrystallized from dimethylformamide.

(E,Z)-3-(6-bromo-4-oxo-2-undecylquinazolin3(4H)-yl)-5-((dimethylamino)methylene)-2iminothiazolidin-4-one (9): Yield 0.56 g 50\%, light brown crystals, mp 302-304 ${ }^{\circ} \mathrm{C}$. IR (KBr) 3340, 1680, 1670, $1617 \mathrm{~cm}-1$. 1H-NMR (300

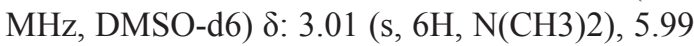
(s, 1H, Ar-H), 7.80 (s, 1H, Ar-H), 8.13 (d, 1H, ArH), 8.5 (s, 1H, NH), 8.35 (d, 1H, Ar-H). MS m/z: 547 (M, 11.8), 468 (16.7), 435 (71.4), 189 (100). Anal. Calcd for C25H34BrN5O2S: C, 54.74; H, 6.25; N, 12.77. Found: C, 54.33; H, 6.30; N, 12.81 .

Synthesis of the benzylidene derivative (E,Z)-10

To a mixture of the thiazolidinone $8(1.0 \mathrm{~g}$, $0.02 \mathrm{~mol})$ and 2-benzylidenemalononitrile[15] $(0.30 \mathrm{~g}, 0.02 \mathrm{~mol})$ in dioxane $(20 \mathrm{ml})$, piperidine $(0.5 \mathrm{ml})$ was added the whole mixture was heated under reflux for two hours. The solid separated on hot was filtered off, dried and recrystallized from dimethyl formamide.

(E,Z)-5-Benzylidene-3-(6-bromo-4-oxo-2undecylquinazolin-3(4H)-yl)-2-iminothiazolidin-4one (10): Yield $0.95 \mathrm{~g} 81 \%$, brown crystals, mp $>300^{\circ} \mathrm{C}$. IR (KBr) 1714, 1668, 1672, $1602 \mathrm{~cm}-1$. 1H-NMR (300 MHz, DMSO-d6) $\delta: 7.02(\mathrm{~s}, 1 \mathrm{H}$, $=\mathrm{CH}), 8.12-7.60(\mathrm{~m}, 9 \mathrm{H}, 8 \mathrm{Ar}-\mathrm{H}+1 \mathrm{H}, \mathrm{NH}) . \mathrm{MS}$ m/z: 580 (M, 100), 442 (12.7), 77 (66.7). Anal. Calcd for C29H33BrN4O2S: C, 59.89; H, 5.72; N, 9.63. Found: C, 60.17; H, 5.66; N, 9.70. 
Synthesis of quinazolinone (E,Z)-11

A solution of dimethyl formamide (10ml) containing a mixture of (dimethylamino)methylene $9(1.0 \mathrm{~g}, 0.02 \mathrm{~mol})$ and phenylmethanamine $(0.22 \mathrm{~g}, 0.02 \mathrm{~mol})$ was refluxed for three hours. The solid deposited on hot was collected by filtration, and recrystallized from dimethyl formamide.

(E)-5-((Benzylamino)methylene)-3-(6bromo-4-oxo-2-undecylquinazolin-3(4H)-yl)-2iminothiazolidin-4-one (11): Yield 0.80 g 73\%, brown light crystals, $\mathrm{mp}>300^{\circ} \mathrm{C}$. IR $(\mathrm{KBr}) 3411$, 3360, 1686, 1672, $1615 \mathrm{~cm}-1$. 1H-NMR (300 $\mathrm{MHz}, \mathrm{DMSO}-\mathrm{d} 6) \delta$ : 5.6 (s, 2H, CH2, Ph-CH2). $6.30(\mathrm{~s}, 1 \mathrm{H},=\mathrm{CH}), 8.41-7.60(\mathrm{~m}, 8 \mathrm{H}, \mathrm{Ar}-\mathrm{H}), 9.12$ (s, 1H, NH), 9.83 (s, 1H, NH), MS m/z: 466 (MH- C10H22, 42.6), 239 (21.8), 91 (100), 77 (83). Anal. Calcd for C30H36BrN5O2S: C, 59.01; H, $5.9 ; \mathrm{N}, 11.47$; S, 5.24. Found: C, 60.29; H, 6.0; N, 11.08; S, 5.09 .

\section{Synthesis of quinazolinone 12}

Following previous methods[20, 21], a suspension of powdered potassium hydroxide $(0.17 \mathrm{~g}, 0.03 \mathrm{~mol})$ in dry dimethyl formamide solution $(20 \mathrm{ml})$, malononitrile $(0.20 \mathrm{~g}, 0.03 \mathrm{~mol})$ and phenyl isothiocyanate $(0.40 \mathrm{~g}, 0.03 \mathrm{~mol})$, were added in portions. The mixture was stirred at room temperature for two hours, and then added to an equal amount of the intermediate IV prepared before (see synthesis of 8). The whole mixture was stirred at room temperature for two hours, poured onto ice-cold water and acidified with $0.1 \mathrm{~N}$ hydrochloric acid at $\mathrm{PH} 3-4$. The resulting precipitate was filtered off, dried and recrystallized from dioxane.

N-(6-Bromo-4-oxo-2-undecylquinazolin3(4H)-yl)-2-((2,2-dicyano-1-(phenylamino)vinyl)

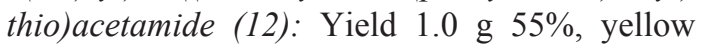
crystals, mp $186-188^{\circ} \mathrm{C}$. IR (KBr) 3310, 3220, 2216, 1708, 1686 Cm-1. 1H-NMR (300 MHz, CDCl3) $\delta: ~ 4.48$ (s, 2H, CH2-CO), 7.62-7.14 (m, $8 \mathrm{H}, \mathrm{Ar}-\mathrm{H}), 8.36,10.0$ each (s, 1H, NH). MS m/z: 420 (54.8), 393 (33.2), 214 (42.2), 92 (100). Anal. Calcd for C31H35BrN6O2S: C, 58.58; H, 5.51; N, 13.22. Found: C, 58.31; H, 5.34; N, 13.1.

\section{Synthesis of compound 13}

Thioether $12(1.0 \mathrm{~g})$ in dioxane $(20 \mathrm{ml})$ was heated for two hour with piperidine $(0.50 \mathrm{ml})$. The reaction mixture was cooled, concentrated $(5 \mathrm{ml})$ and acidified with dilute hydrochloric acid. The solid separated was collected by filtration, Egypt.J.Chem. 60 , No.6 (2017) washed several times with dilute methanol and crystallized from methanol.

3-Amino-N-(6-bromo-4-oxo-2-undecylquinazolin3(4H)-yl)-4-cyano-5-(phenylamino) thiophene-2carboxamide (13): Yield 0.64 g 64\%, yellow crystals, mp $205-207^{\circ} \mathrm{C}$. IR (KBr): 3413, 3342, 3252, 2170, $1663 \mathrm{~cm}-1$. 1H-NMR $(300 \mathrm{MHz}$, DMSO-d6) $\delta: 7.62-7.08(\mathrm{~m}, 8 \mathrm{H}, \mathrm{Ar}-\mathrm{H}), 8.53$, 10.11 each (s, 1H, NH), 10.56 (br.s, 2H, NH2). Anal. Calcd for C31H35BrN6O2S: C, 58.58; H, $5.5 ; \mathrm{N}, 13.22$. Found: C, 58.43; H, 5.38; N, 13.15.

\section{Results and Discussion}

6-Bromo-2-undecyl-4H-benzo[d][1,3] oxazin-4-one (1) was prepared by reaction of dodecanoylchloride with 2-amino-5bromobenzoic acid, following the most expedition method[13] (Figure 1). The structure of 1 was inferred from its IR spectrum that revealed strong absorption bands at 1757 and $1642 \mathrm{~cm}$ 1 , attributable to absorption band for $\mathrm{C}=\mathrm{O}$ and $\mathrm{C}=\mathrm{N}$, group respectively. Further support for the assigned structure was gained from its $1 \mathrm{H}-\mathrm{NMR}$ which is in accord with the proposed structure. The EI-MS disclosed a molecular ion peak at $\mathrm{m} / \mathrm{z}$ (379) together with $[\mathrm{M}+2]$ peak in the ratio $\approx 1: 1$ feature of bromo compounds.

The study program comprised synthesis of new 3-substituted quinazolin-4-one derivatives via the reactions of the $[3,1]$ benzoxazin-4-one 1 with the nitrogen nucleophiles; hydrazine hydrate, ethyl carbazate, 4-tolylsulfonohydrazide and 2-cyanoacetohydrazide[14], in hot dioxane, to give the quinazolinone derivatives 2- 5 (Fig. $1)$. The structures of 2- 5 were substantiated by different spectral data (see experimental). The route of these reactions is supposed to involve heteroring opening, by the lone pair of electrons of the nitrogen atom, at the carbonyl group presented in position-4 of the oxazinone ring, leading to the hydrazide I as a fleeting intermediate which in turn, afforded the 3-substituted derivative 2-5 via an intramolcular 6-exo-trig cyclization (Fig.1).

Furthermore, treatment of cyanoamide 5 with piperidine in boiled dioxane, affected an intra-molcular cyclo-condensation process providing the pyrazoloquinazoline derivative 6 (Fig. 1). The infrared spectrum of 6 showed 
stretching absorption band for only one $\mathrm{C}=\mathrm{O}$ at $1633 \mathrm{~cm}-1$ and its ${ }^{1} \mathrm{H}-\mathrm{NMR}$ did not show any signals for the - $\mathrm{CH} 2-$ protons. Disappearance of these moieties which were found in spectra of the starting 5 is a good evidence for the proposed condensation process.

Since reactions of amines with phenyl isothiocyante give thiourea derivatives[16,17] which are useful in synthesis of 1,3-thiazolidin4-ones[18,19], the amine derivative 2 was conducted to react with phenyl isothiocyante, and in situ generated thiourea then allowed to react, (in the form II), with 2-chloroacetonitrile, 1-chloropropan-2-one and ethyl 2-chloro3-oxobutanoate providing 3-(1,3-thiazol-2ylidene)quinazolin-4-ones $7 \mathrm{a}-\mathrm{c}$, via the expected intermediate III (Fig. 2).

Moreover, stirring amine 2 with 1,2-dichloroethanone at room temperature yielded the intermediate IV, which in situ was followed by a treatment with potassium thiocyanate, providing the quinazolin-4-(3H)-one 8 , via 5-exodig cyclization (Fig. 2).

The latent thiazolidin-4-one ring presented in compound 8 was utilized in synthesis of polyfunctionlity 1,3-thiazolidin-4-ones. Thus, reactions of 8 with dimethylformamidedimethylacetal, and 2-benzylidenemalononitrile[15] gave the quinazolin-4(3H)-ones 9 and 10 , respectively (Fig. 2). In addition, treatment of 9 with phenylmethanamine provided the corresponding 5-benzylimino derivative 11 (Fig. 2).

The IR, 1HNMR and EI-MS spectra of compounds 8-11 are in accord with the proposed structures (see experimental). In EI-MS of 11, the molecular ion peak was missed but it showed a base peak at $\mathrm{m} / \mathrm{z}=91$ for the expected tropylium cation $(\mathrm{C} 7 \mathrm{H} 7+)$.

On the other hand, treatment of ketene N,Sacetal adduct V (Fig. 3) with the previously prepared intermediate IV (see Fig. 2) provided the thioether 12 which was motivated with piperidine to an intramolcular cycloaddition, forming the aminothiophene derivative 13 (Fig. 3). It is worth to indicate that the N,S-acetals of the type $\mathrm{V}$ have been early prepared[20, 21]. The infrared and $1 \mathrm{H}-\mathrm{NMR}$ spectra of thiophene 13 revealed the presence of the newly formed -NH2 group.

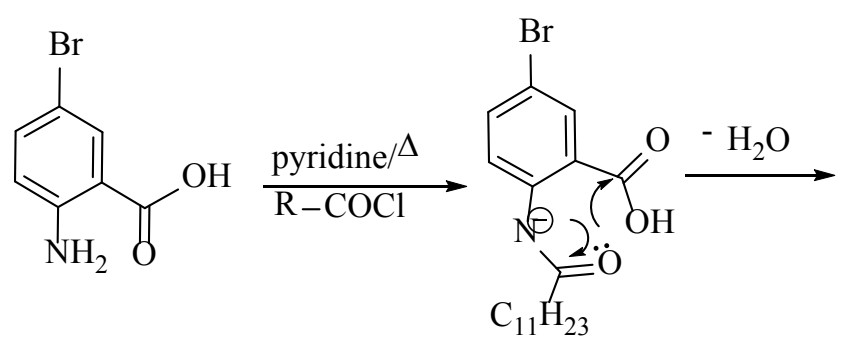

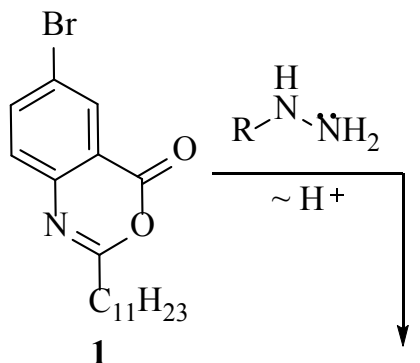

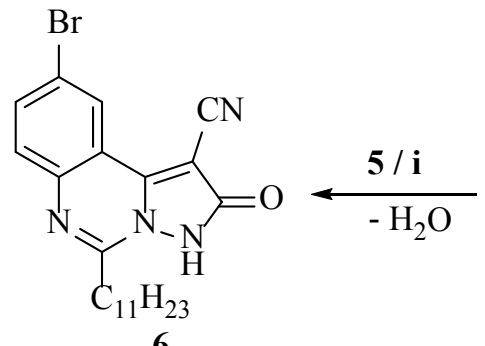

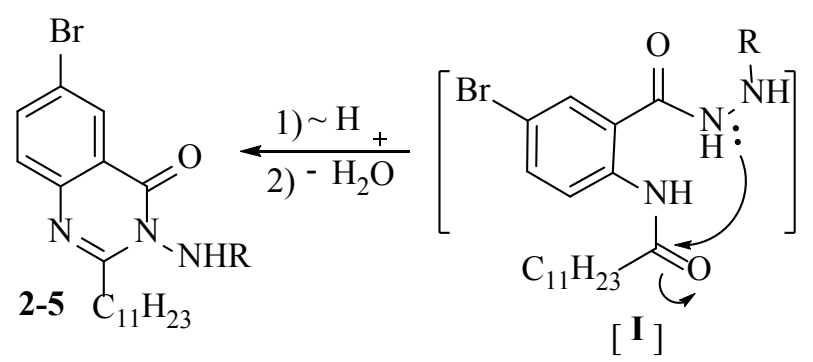

2; $\mathrm{R}=\mathrm{H}, 3 ; \mathrm{R}=\mathrm{CO}_{2} \mathrm{Et}, 4$; $\mathrm{R}=p$-tosyl, 5; $\mathrm{R}=\mathrm{COCH}_{2} \mathrm{CN}$

$\mathbf{i}=$ dioxane $/$ piperidine $/ \Delta$

Fig.1. Synthesis of compounds 1- 5 . 


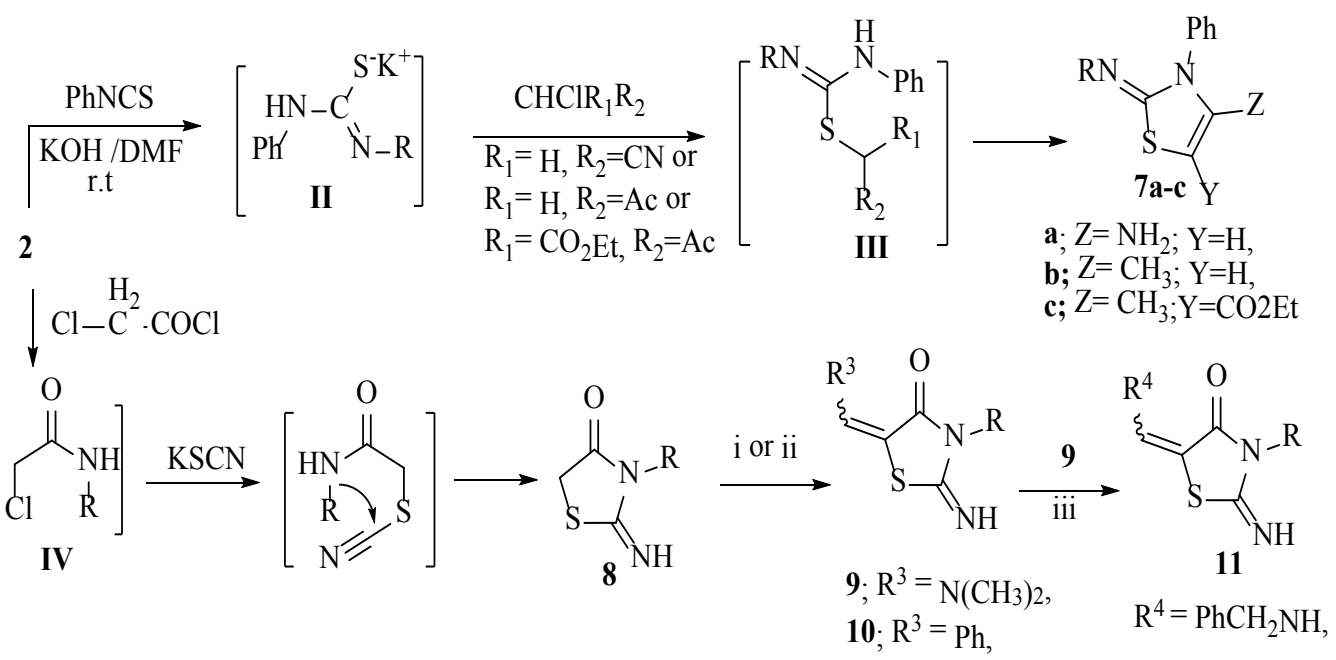

$\mathrm{i}=\mathrm{DMF}-\mathrm{DMA} /$ toluene $/ \Delta$ ii $=$ dioxane $/$ pip $+(\mathrm{NC})_{2} \mathrm{C}=\mathrm{CHPh}$ iii $=$ dioxane $/ \Delta / \mathrm{PhCH}_{2} \mathrm{NH}_{2}$

$\mathrm{R}=$ 6-bromo-2-undecylquinazolin-4(3H)-one-3-yl

Fig.2. Synthesis of compounds 7- 11 .

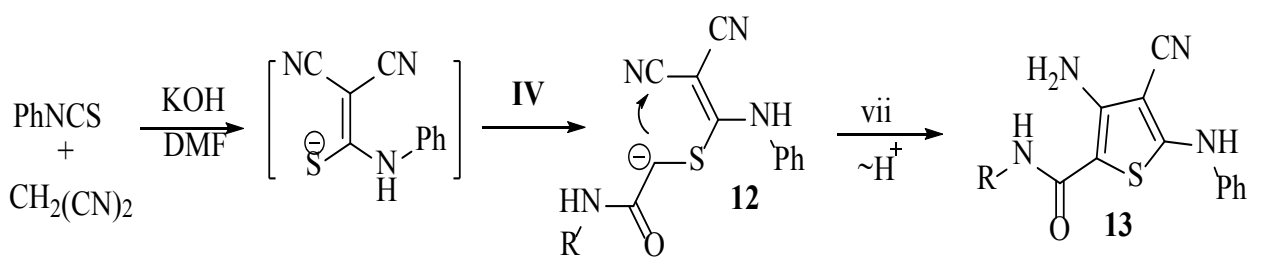

$\mathrm{R}=$ 6-bromo-2-undecylquinazolin-4(3H)-one-3-yl $\quad$ vii = piperidine $/$ dioxane $/ \Delta$

Fig.3. Synthesis of 12 and its conversion into 13.

\section{Antibacterial activity}

By the exception of 3,5 and 12, all of the synthesized compounds were assayed in vitro by agar well diffusion method[22] against five bacterial species e.g. Escherichia coli, Shigella flexneri and Salmonella typhi were Gram negative and Staphylococcus and Bacillus Subtilis were Gram positive bacteria.

The results were displayed in Table 1 for Gram positive bacteria and in Table 2 for Gram negative bacteria, compared with the antibacterial drugs Amoxicillin and Streptomycin.

Most of compounds showed the bacterial Egypt.J.Chem. 60 , No.6 (2017) activities against the strains Gram negative bacteria. Compounds 2, 4, 8, and 13 had shown no bactericidal activity against Gram negative or Gram positive bacteria. Compounds 1, 6, 7a, 7b, $7 \mathrm{c}, 9$ and 10 showed good to moderate activity against Escherichia coli and Shigella flexnari bacteria.

Compounds 1, 6, 7a and 9 showed weak activity against Salmonella typhi. Only 6-bromo3-(5-((dimethylamino)-methylene)-2-imino-4oxo-1,3-thiazolidin-3-yl)-2-undecylquinazolin$4(3 \mathrm{H})$-one 9 was the compound which showed good activity against Bacillus subtilis. 
TABLE 1. Antibacterial activity of compounds against Gram negative bacteria results expressed as (inhibitory zone diameter/ $\mathrm{mm}$ ).

\begin{tabular}{cccc}
\hline Compd. & & Gram negative bacteria & \\
& Escherichia coli & Shigella flexneri & Salmonella typhi \\
\hline $\mathbf{1}$ & 12 & 17 & 13 \\
$\mathbf{6}$ & 12 & 11 & 13 \\
$\mathbf{7 a}$ & 16 & 13 & 12 \\
$\mathbf{7 b}$ & 10 & 11 & 0 \\
$\mathbf{7 c}$ & 18 & 15 & 0 \\
$\mathbf{9}$ & 17 & 12 & 10 \\
$\mathbf{1 0}$ & 18 & 18 & 0 \\
Amoxicillin & 20 & 25 & 27.5 \\
Streptomycin & 28.5 & 28.5 & 33.5 \\
\hline
\end{tabular}

TABLE 2. Antibacterial activity of compounds against Gram positive bacteria; results expressed as (inhibitory zone diameter/ $\mathbf{m m}$ ).

\begin{tabular}{ccc}
\hline Compd. & $\begin{array}{c}\text { Gram positive bacteria } \\
\text { Staphylococcus }\end{array}$ & $\begin{array}{c}\text { Bacillus } \\
\text { Subtilis }\end{array}$ \\
\hline $\mathbf{1}$ & & 0 \\
$\mathbf{6}$ & 0 & 10 \\
$\mathbf{7 a}$ & 10 & 0 \\
$\mathbf{7 b}$ & 0 & 0 \\
$\mathbf{7 c}$ & 14 & 0 \\
$\mathbf{9}$ & 0 & 14 \\
10 & 12 & 0 \\
Amoxicillin & 15 & 15.3 \\
Streptomycin & 27.5 & 16 \\
\hline
\end{tabular}

\section{Conclusion}

Thirteen of 2,3-disubstituted quinazolin4- $(3 \mathrm{H})$ one derivatives were synthesized and evaluated for bacterial activity against five pathogenic microorganism. In conclusion these compounds possess a broad spectrum of activity against a group of Gram negative bacteria, responsible for causing most common bacterial diseases. However, few members were active against Gram positive bacteria. This study opens the possibility of finding new clinically effective bactericidal compounds.

\section{References}

1. Hamel E., Lin C. M., Plowman J., Wang H. K., Lee K. H. and Paul K. D., Antitumor 2,3-dihydro-2(aryl)-4-(1H)-quinazolinone derivatives: Interactions with tubulin. Biochem. Pharmacol, 51, 53-59 (1996).

2. Farghaly A. M., Soliman R., Khalil M. A., Bekhite
A. A., El Din A. and Bekhit, A., Thioglycolic acid and pyrazole derivatives of $4(3 \mathrm{H})$ quinazolinone: synthesis and antimicrobial evaluation.Boll. Chem. Farm. 141, 372-378 (2002).

3. Bartroli J., Turmo E., Alguero M., Boncompte E., Vericat M L., Coule L., Ramis J., Merlos M., Garcia R. J. and Forn J., New azole antifungals. 3. Synthesis and antifungal activity of 3-substituted4(3H)-quinazolinones. J. Med Chem. 41, 18691882 (1998).

4. Fathalla O.A., Kassem E. M. M., Neama A. M. and Kamel M. M., Synthesis of some new quinazoline-4-one derivatives and evaluation of their Antimicrobial and anti-inflammatory effect. Acta Pol. Pharm. Drug Res. 65, 11-20 (2008).

5. Eguchi, S., Suzuzi, T., Okawa. T., Matsushita, Y., Yashima, E. and Okamoto, Y., Synthesis of optically active vasicinone based on intramolecularaza-wittig reaction and asymmetric oxidation. J. Org. Chem. 61, 7316-7319 (1996).

6. Bergman J. and Brynolf, A., Synthesis of chrysogine, a metabolite of penicilliumchrysogenum and some related 2-substituted 4-(3H)-quinazolinones. Tetrahedron, 46, 1295-1310 (1990) .

7. Kacker I.K. and Zaheer S. H., Synthesis of substituted 4-quinazolones. J. Indian Chem. Soc.28, 344-346 (1951).

8. Takeuchi Y., Abe H. and Harayama T., Total synthesis of dl-febrifugine and dl-isofebrifugine. Chem. Pharm. Bull. 47, 905-906 (1999).

9. Keller T. L., Zocco D., Sundrud M.S., Hendrick M., Edenius M., Yum J., Kim Y.J., Lee H. K., Cortese J. F., Wirth D.F., Dignam J. D., Rao A., Yeo C. Y., Mazitsche K. R. and Whitman M., Halofuginone

Egypt.J.Chem. 60 , No.6 (2017) 
and other febrifugine derivatives inhibit prolyltRNAsynthetase.Nat ChemBiol, 8, 311-317(2012).

10. Mahmoud M. R., El-Bordany E. A. A., Naglaa F. H. and Fatma S. M., New 2,3-disubstituted quinazolin-4(3H)-ones from 2-undecyl-3,1-benzoxazin-4-one. J. Chem. Res. 541-544 (2007).

11. Brown F. C., 4-Thiazolidinones. Chem. Rev. 61, 463-521. (1961).

12. Singh, S. P., Parmar, S. S., Raman, K. and Stenberg V. I., Chemistry and biological activity of thiazolidinones. Chem. Rev. 81, 175-203 (1981).

13. Revelant G., Huber-Villaume S., Dunand S., Kirsch G., Schohn H. and Hesse S., Synthesis and biological evaluation of novel 2-heteroarylimino1,3-thiazolidin-4-ones as potential anti-tumor agents. Eur. J. Med.Chem.94, 102-112 (2015).

14. Bondock S., Tarhoni A. E.G. and Fadda A. A., Utility of cyanoacetic acid hydrazide in heterocyclic synthesis. Arkivoc, (ix) 113-156 (2006).

15. Nosachev S. B., Shchurova N. A. and Tyrkov A. G., Reactions of 2-benzylidene-malononitrile and 2-nitro-3-phenylacrylonitrile with aryl azides. Russ. J. Org. Chem. 47, 577-580 (2011).

16. Coburn A.R. andGlennon R.A. Mesoionicpurinone analogs.7. In vitro antibacterial activity of mesoionic 1,3,4-thiadiazolo[3,2,-a]pyrimidine- 5,7-diones. J. Med. Chem. 17, 1025-1027 (1974).

17. Samia M. S., Mohamed A. R. and Kamal M. D., Synthesis and reactivity of phenylthiourea derivatives: an efficient synthesis of new thiazolebased heterocycles. J. Heterocyclic Chem., 53, 508-512 (2016).

18. Liebermann C. and Lange A., Ueber die formeln der snlfhydantoine. Ber Dtsch Chem Ges.12, 1588-1595 (1879).

19. Chande M. S. and Ambhaikar S. B., 2-Alkyl/ arylamino-5-carbethoxythiazolidine-4-one: A new synthons for the synthesis of spiro and fused ring heterocycles. Indian J. Chem. 35B, 373-376(1996).

20. Rudorf W. D., Schierhorn A. and Augustin M. Reaktionen von o-halogen-acetophenonen mit schwefelkohlenstoff und phenylisothiocyanat. Tetrahedron, 35, 551-556 (1979).

21. Farhat M.F., El-Saghier A.M.M., Makhlouf M.A. and Elmezoughi A.B., Ketene $N, S$-acetals in heterocyclic synthesis: Part1: Synthesis of N-phenyl-2-ylidene and 2,5-diylidene-4-thiazolidinone Derivatives $J$. Sulfur Chem. 28, 563-572 (2007).

22. Jacobs M. R. and Appelbaum, P. C., Antibioticresistant pneumococci. Rev Med Microbiol. 6, 7793 (1995)

(Received 12/ $10 / 2017$; accepted 5/ 11/ 2017)

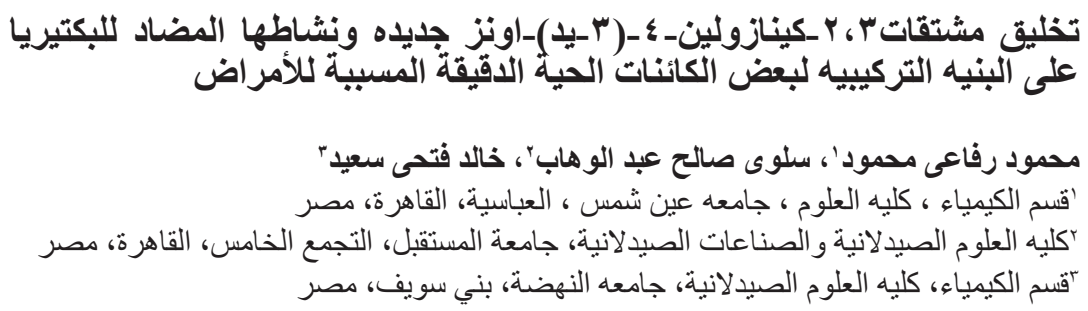

تم تخليق سلسله عاليه الفائده من الكينازولين_ع_اونزبها مشتقات مختلفه فى الموضع باّ، بطريق مختصر وبمحصول

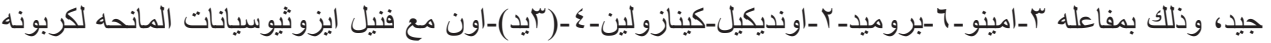

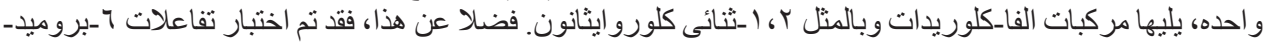

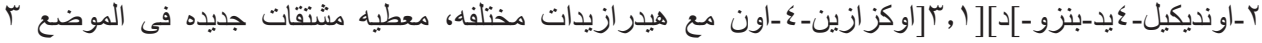

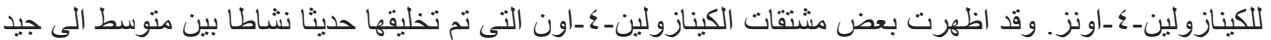

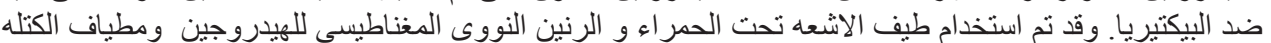
للتحقق من تركيبات جميع هذه النو اتج الجنديده 